\title{
The World Experience and a Unified Model for Government Regulation of Development of the Automotive Industry
}

\author{
Illia A. Dmytriiev, Inna Yu. Shevchenko, Vyacheslav M. Kudryavtsev, Olena M. Lushnikova \\ Department of Economics and Entrepreneurship \\ Kharkiv National Automobile and Highway University \\ 61002, 25 Yaroslav Mudriy Str., Kharkiv, Ukraine
}

Tetiana S. Zhytnik

Department of Social Work, Social Pedagogy and Preschool Education

Bogdan Khmelnitsky Melitopol State Pedagogical University

72300, 20 Hetmanska Str., Melitopol, Ukraine

cross $^{\text {ref }}$ http://dx.doi.org/10.5755/j01.ppaa.18.3.24720

\begin{abstract}
The article summarises the advanced world experience in government regulation of the automotive industry using the example of the leading automotive manufacturing countries China, Japan, India, South Korea, the USA, and the European Union. Leading approach to the study of this problem is the comparative method that has afforded revealing peculiarities of the primary measures applied by governments of the world to regulate the automotive industry have been identified. A unified model for government regulation of the automotive industry has been elaborated. The presented model contains a set of measures for government support for the automotive industry depending on the life cycle stage (inception, growth, stabilisation, top position, stagnation, decline, crisis) of the automotive industry and the level (high, medium, low) of competitiveness of automotive enterprises.
\end{abstract}

Keywords: automotive manufacturing, competitiveness, life cycle, industrial sector, world experience.

Raktažodžiai: automatizuota gamyba, konkurencingumas, gyvavimo trukmé, gamybos sritis, pasauline patirtis

\section{Introduction}

The automotive industry is an integral and strategically important part of the industrial sector and national economy as a whole, traditionally making a significant contribution to the formation of gross domestic product, attraction of investment, and creation of jobs. Today, the automotive industry is actively developing: with each passing year, the volume of production and sales of cars, trucks, and buses is increasing. However, such a positive trend in the automotive industry is typically not for all countries with automotive sectors.

According to the International Organization of Motor Vehicle Manufacturers, as of the beginning of the 2018, the top 10 global automakers in terms of passenger car production were China (24,806 thousand cars were manufactured in 2017), Japan (8,347 thousand cars), Germany (5,645 thousand cars), India (3,952 thousand cars), South Korea (3,735 thousand cars), the USA (3,033 thousand cars), Spain (2,291 thousand cars), Brazil (2,269 thousand cars), Mexico (1,900 thousand cars), and France (1,748 thousand cars) (World motor vehicle production by country and type, 2017). In the global truck manufacturing, the leading positions are taken by automakers from China $(2,257$ thousand trucks were manufactured in 2017), Japan (515 thousand trucks), India (283 thousand trucks), the USA (280 thousand trucks), Mexico (167 thousand trucks), Indonesia (86 thousand trucks), South Korea ( 85 thousand trucks), Brazil (82 thousand trucks), Italy (67 thousand trucks), 
and Russia (also 67 thousand trucks) (World motor vehicle production by country and type. Trucks, 2017). In 2017, the most significant contribution to the global manufacturing of buses was made by automakers from China (178 thousand buses), India (42 thousand buses), South Korea (14 thousand buses), Russia (12 thousand buses), and Japan (also 12 thousand buses) (World motor vehicle production by country and type. Buses, 2017). Thus, it is possible to assert with confidence that at present, the world leaders in motor vehicle manufacturing are China, Japan, India, South Korea, the USA, and the European Union.

While countries of the post-Soviet space (including Ukraine) experience a decrease in the volume of production and sales of motor vehicles, and as a result lose their competitive positions in the national market in the struggle with foreign automakers (Akhmetshin et al., 2019). This situation requires strengthening government regulation of the automotive industry in Ukraine, efficiency of such measures widely depending on adopting international best practices (Ripetskiy et al., 2018).

The need to strengthen government regulation of the automotive industry in the post-Soviet countries is emphasized in scientific works of a number of researchers, including O. Kryvokon and A. Bondarenko (2012), O. Krause and A. Mashchak (2018), O. Andreev (2009), P. Kerimov (2017), A. Ostapenko (2015), V. Prikhodko (2014), O. Semyrak (2016), V. Siumar (2008), A. Chernikov (2016). However, the scientists did not pay attention to generalising and unifying the advanced foreign experience in government regulation of the automotive industry. Thus, singling out China, Japan, India, South Korea, the United States, and countries of the European Union as the most successful motor vehicle manufacturers, we consider it necessary to prioritise studying features of government regulation of the automotive industry in these countries and unify them as a model. So, the purpose of the article is exploring the world experience in government regulation of the automotive industry and consolidating it as a model.

\section{The main features of government regulation of the automotive industry in the leading automotive manufacturing countries}

Automotive industry in China. The history of the Chinese automotive industry dates back a little more than half a century: for example, the first automotive manufacturing plant was opened in the country only in 1953 . The next decade was marked by a gradual increase in production capacity of China's automotive industry through the opening of automotive plants in Nanjing, Shanghai, Jinan, and Beijing. However, the volume of production of motor vehicles remained low, which stimulated the import of automotive products from neighbouring countries, in particular, Japan and the Soviet Union.

Understanding that the development of the automotive industry requires government support was reflected in the actions of the Chinese government in the 1980s. Thus, an import duty on motor vehicles in the amount of $200 \%$ of their customs value was established. Along with restricting the import of automobiles into China, steps were taken to attract foreign capital into the country. In particular, this was reflected in the mandatory requirement that the share of foreign investment in the authorised capital of the automotive industry had to be at least $50 \%$. Moreover, measures were taken to attract advanced motor vehicle production technologies through the conclusion of several agreements on assembling American (Jeep), German (Volkswagen), and French (Peugeot) vehicle brands. At the same time, the development of the automotive industry was ensured by requirements for the level of production localisation: it was established that in the first year of motor vehicle assembling at least $40 \%$ of components should be of local origin, in three years $-80 \%$. In the 1990s, the domestic production of automobiles stabilised, for the first time its volume reached the value of 1 million. Realising the impossibility of the isolation from the global automotive market, the government gradually reduced the import duty to $120 \%$.

In 2000, the import duty on motor vehicles was cut to $100 \%$, in $2001-$ to $70-80 \%$, in 2002 - to 40-60 \%. In 2001, China became a member of the World Trade Organization and reduced import duties on motor vehicles produced by WTO member countries to $26 \%$. These actions accelerated the 
development of China's automotive industry. In 2004, its production volume exceeded 5 million vehicles.

In 2009, China became the leader of the global automotive industry, having produced more than 13 million motor vehicles. The total production was almost evenly distributed between national and foreign brands. At the same time, the vast majority of motor vehicles produced in China, as a rule, were sold on the domestic market.

Starting from 2010, the gradual curtailment of programs to stimulate the development of the domestic motor vehicle market began. The sales tax on small cars was increased to $10 \%$. Moreover, in connection with the achievement of a critical level of automobilisation, control over the growth of the motor vehicle fleet was introduced in the cities of Shanghai and Beijing. In the same period, the government of the People's Republic of China started implementing measures to stimulate sales of hybrid and electric cars by giving citizens government subsidies for the purchase of these types of vehicles. However, as soon as in 2018, the size of subsidies for purchasing plug-in cars was revised due to the rapid growth in sales of electric and hybrid cars (by $50 \%$ per year): subsidies for electric vehicles with a driving range of up to $150 \mathrm{~km}$ were reduced, while for those with more than $400 \mathrm{~km}$ range -raised. It was planned to further cur the amount of subsidies for purchasing electric vehicles and hybrids by $30 \%$ in 2019. In 2020, government subsidies for purchasing a plug-in car can be cancelled completely (Kryvokon and Bondarenko, 2012; Krause and Maschak, 2018; Andreev, 2009)

Automotive industry in Japan. Japan's automotive industry has a long and glorious history, the beginning of which dates back to 1904. In the period before World War II, the Japanese oligarchy (the business conglomerates of Mitsubishi Group, Isuzu Motors, Nissan Motor) produced motor vehicles in close cooperation with American and European automakers, namely, General Motors, Ford Motor Company, Chrysler, Wolseley Motors, Austin Motor Company, Fiat Automobiles.

The rapid growth in demand for trucks in the prewar period allowed the Japanese automakers to create their own models of automotive products. During that period, the innovative potential of Japanese automakers was intensively formed: in particular, the Kaizen system was constantly being introduced into practice. The truck industry had become the basis of Japan's automotive industry by the end of the 1960s.

Understanding the need to maximize satisfaction of the internal demand for cars (and, above all, for cars for personal use of the population) with domestic automotive production, the Japanese government took measures to allocate quotas for the number of cars imported into the country: in the period 1948-1965, it was allowed to import ambulance vehicles as well as vehicles for media and tourism. Until 1968, the import duty on motor vehicles was $40 \%$. Until 1970, there was a restriction on the import of automobiles by foreign exchange quotas. In order to support manufacturers of cars with small cylinder capacity, a differentiated sales tax was introduced: cars with an engine capacity of up to $2 \mathrm{~L}-20 \%$, cars with an engine capacity of $2-3 \mathrm{~L}-30 \%$, cars with an engine capacity of more than $3 \mathrm{~L}-50 \%$. Moreover, the government took measures to regulate investment activities of enterprises: access of foreign capital to the marketing sector of the automotive industry was denied; investments in the production of motor vehicles were supported only if they stimulated domestic production (investment contracts provided for a 90\% localization) and export of automobiles and, accordingly, reduced imports of automotive products; for joint ventures, the presence of a Japanese partner, one of the leading manufacturers of chassis, was mandatory (Kryvokon and Bondarenko, 2012). These measures for government support for the automotive industry in the complex have led to fierce competition among automakers in the Japanese market.

The 1970s are associated with the robust expansion of the Japanese automakers in the global car market, which continued over the period 1980-1990. The beginning of the new millennium was marked by stricter environmental requirements for cars in Japan during 2009-2012. The government introduced tax cuts on new environmentally friendly and cost-effective cars: complete exemption from the tax on sale of electric vehicles, cars with a hybrid powertrain and using alternative fuels; 75 $\%$ reduction in the tax on sale of eco-friendly and fuel-efficient cars. Such market incentives 
contributed to the rapid growth of the market share of hybrid and environmentally-friendly vehicles to $65 \%$ (Ostapenko, 2015).

The demand for electric vehicles in Japan and the world is mainly satisfied by the Nissan Leaf model, but Japanese automakers are actively developing hydrogen fuel cell cars (Toyota Mirai, Honda Clarity Fuel Cell). The government of the country has already announced that the new products will be included in the program of government subsidies for purchasing eco-friendly cars.

Automotive industry in the European Union. It is believed that European governments are not actively interfering in the economy, and economic activity in the EU countries is carried out only on the basis of a market mechanism. However, the European Commission pursues an active policy to stimulate production of motor vehicles and prevent saturation of the market with imported automobiles. Thus, the European Union has restricted the import of vehicles from Japan, while EU countries actively promote their products to the Japanese market.

One of the most effective tools of government support for the automotive industry in the European Union is subsidising. Subsidies to automakers in EU countries are carried out by exemption from direct taxes; direct investment; provision of government loans to automakers at concessionary interest rates; provision of government guarantees to automotive enterprises' creditors on financial markets (Semyrak, 2016).

The EU automotive industry has the characteristics of an oligopolistic market with moderate competition. Therefore, subsidies are provided in larger volumes than in monopolised markets. To streamline their provision, the European Commission periodically develops framework guidelines that specify the permissible reasons for paying subsidies to automakers as well as their parameters.

The main reasons for subsidising motor vehicle manufacturers in the EU are as follows: stimulating regional development; restructuring automotive plants; carrying out "horizontal" activities. The intensive supporting of automakers to encourage local development is proportional to the drawbacks of the infrastructure of backward regions and takes into account the possible distortion of competition in this market segment. Examples of subsidising automakers to stimulate regional development are such joint ventures as General Motors/Opel (Portugal), Volkswagen/Seat (Spain). A subsidy for restructuring an automotive plant is provided in case of merger and acquisition of automotive concerns; significant losses incurred by motor vehicle manufacturers due to a decline in consumer demand for automobiles; threat of substantial reduction in the number of employees. A mandatory condition for subsidising is the existence of a restructuring plan, which envisages specific measures for the exit of the enterprise from the crisis. Subsidies for restructuring were provided, in particular, to such joint ventures as Volkswagen/Seat (Spain) and DAF (Netherlands).

The so-called "horizontal" activities are a promising and most progressive basis for obtaining subsidies by automotive plants of the European Union. Such "horizontal" activities include scientific and technical research; innovation, modernisation and rationalisation of production; environmental protection and energy conservation measures; staff training and development. Subsidies to automotive enterprises of the EU are provided mainly from the budget of EU countries, although sometimes the resources of the EU regional fund and the European Investment Bank are used (Andreev, 2009).

In the European Union, much attention is paid to strengthening environmental requirements for motor vehicles. Thus, the EU Council have decided to increase the number of automobiles with an electric or hybrid engine to $35 \%$ of the entire passenger car fleet of countries of the Community by 2030 . By the same decision, the EU Council adopted quotas for the average carbon dioxide content in vehicle emissions, which should be reduced by $15 \%$ by 2025 and by $35 \%$ by 2030 compared to the 2021 level. By 2021, the average carbon dioxide content in car emissions should be 95 grams of $\mathrm{CO}_{2}$ per kilometre, which corresponds to a consumption rate of 4.1 litres of gasoline per $100 \mathrm{~km}, 3.6$ litres of diesel fuel per $100 \mathrm{~km}$. These restrictions at the legislative level will contribute to the withdrawal of technically sound but obsolete in terms of environmental performance cars out of traffic (The EU agreed to limit $\mathrm{CO}_{2}$ emissions by the new vehicles from 2030). 
Automotive industry in India. India's automotive industry began its history in the 1940s. Since the establishment of such enterprises as Hindustan Motors, Premier Automobiles, Mahindra \& Mahindra is specialising in assembling cars of American brands Chrysler, Dodge, and Jeep. After India gained independence in 1947, the government began to pursue an active policy of refusing the role of a platform for assembling cars of foreign brands and establishing its own motor vehicle production. In 1952, the government of India created the Tariff Commission, the implementation of decisions of which resulted in the import substitution program. The average import duty on motor vehicles was $135 \%$, and for kits for Complete Knock Down (CKD) assembly - $40 \%$. Moreover, the licensing of foreign investment in the automotive industry was introduced. The situation did not suit the American partners, and they decided to exit the car market in India.

Throughout 1950-1980, India's automotive industry was developing at a rather slow pace, which was primarily constrained by low domestic demand for motor vehicles, given the insolvency of the majority of the population. The main customers of Indian automakers were agricultural enterprises. The lack of domestic demand for automobiles and the lack of its own financial resources made India's automotive plants produce vehicles by preliminary order (Ostapenko, 2015). It became apparent that the automotive industry in India requires substantial external incentives, primarily, financial support. The Indian government did not have sufficient funds in the early 1990s. Thus, it was decided to partially remove the restrictions on foreign investment in the automotive industry.

The first positive experience in the joint motor vehicle production was the collaboration of the Indian Maruti Udyog with the Japanese Suzuki. Today, Maruti Suzuki India Limited is a leading car manufacturer in South Asia with an annual production volume of more than 1 million cars. The unique combination of advanced technologies applied in the production of Suzuki cars along with the minimisation of production costs based on Maruti Udyog led the joint venture to monopoly domination in the Indian passenger car segment in the late 1990s. In 1996, to rival Maruti Suzuki India Limited, Hyundai Motor India Limited (founded by the South Korean automaker Hyundai Motor Company), which managed to become the second-largest car manufacturer in India, entered the Indian car market. Despite the significant positive effects of joint motor vehicle manufacturing, the government of India is in no hurry to give up restrictions on foreign investment in the automotive industry: for example, the share of foreign investment in the authorized capital of automakers is still regulated, and in case if it exceeds $51 \%$ such enterprises are considered individually by the Foreign Investment Promotion Council.

Foreign investment and the transfer of automotive technology to India have contributed to the development by its automakers of their competitive models of motor vehicles. In 2001, to protect the domestic market, the government of India introduced a temporary ban on imports of foreign cars. The gradual increase in the domestic motor vehicle production and insufficient domestic demand naturally led to a surplus of motor vehicles in the country and the start of their export in the 2000s. As soon as in 2009, India's motor vehicle exports amounted to the equivalent of USD 4.5 billion, in 2014 - USD 14.5 billion (Kryvokon and Bondarenko, 2012; Semyrak, 2016). At present, the domestic demand for cars in India is almost completely satisfied by national manufacturers. Purchasing an imported car in the country is possible, but an import duty of $105 \%$ should be paid.

It is fair to note that in addition to licensing foreign investment in the automotive industry and the active production of protective customs policies, other methods of government incentives for the development of the automotive industry were applied in India, including: government concessional loans for automakers, tax refund for exporting automakers, large government orders for motor vehicle production, reduction in VAT rate and service tax on cars, introduction of accelerated depreciation for commercial vehicles, encouraging banking institutions to introduce credit programs for the purchase of commercial vehicles (Kryvokon and Bondarenko, 2012; Ostapenko, 2015).

Automotive industry in South Korea. The beginning of the automotive industry in South Korea dates back to 1962 when the government announced the "Policy for the Promotion of the Automotive Industry" as the vital national industry. However, the newly formed automotive manufacturing enterprises had neither capacity for independent production of automobiles nor experience in this 
area. Very soon, it became evident that there was the need to attract foreign investment and advanced foreign technologies for the country to start production of its own vehicles. South Korean enterprises engaged in the automotive industry were actively beginning to assemble automobiles from imported components.

While South Korean automakers were increasing their capacity, adopting advanced technologies and best practices of motor vehicle production in accordance with international standards and stabilizing their financial condition, the government actively carried out numerous activities to develop related industries such as mechanical engineering, steel production, chemical industry, and electronics in accordance with the "Policy for the development of the heavy and chemical industries". First of all, the development of related industries in South Korea was aimed at ensuring maximum localisation of the production of parts and components for assembling motor vehicles (Stroe and Andrei, 2017).

When the necessary level of localisation was reached (late 1960s), the South Korean government decided to ban imports of parts and components for assembling vehicles. The only exceptions were the most technologically complex parts of vehicles, the import of which was allowed to carry out without paying import duties, but only until their production was localised. The South Korean government continued the policy of specialization and localization of motor vehicle assembly in the early 1970s, starting the implementation of the "One manufacturer for one type of product" policy, which, in particular, required an automotive assembly plant to have equipment for the production of main vehicle parts (engine and body). The period associated with motor vehicle assembling in the history of the development of the automotive industry in South Korea lasted until 1974 (Andreev, 2009).

In 1974, the South Korean government decided to start the national motor vehicle production based on the leading automotive assembly plants, namely, Shinjin Motors, Asia Motors, Hyundai Motors and Kia Motors. In the same period, automotive products were declared the main export destination. The selected enterprises received substantial support from the government of the country, including financial incentives in the form of concessional loans and provision of public financing to develop the technical and technological base of the automakers. However, enterprises were required to strictly adhere to the policy of localising the motor vehicle production: for example, according to the plans of the government, by 1980 the level of localisation of manufacturing parts and components in motor vehicle assembly was expected at the level of at least $90 \%$. The volumes of own vehicle production by each of the selected automotive manufacturing plants were scheduled to be at least 50 thousand automobiles per year. In 1987, the South Korean government founded the program "People's Car": the class of cars that were in the highest demand (cars with an engine capacity of up to 800 cubic centimetres and dimensions of $3500 \times 1500 \times 2000 \mathrm{~mm}$ ) was determined, and the excise duty on such vehicles was abolished. In 1988, to support national automakers and protect them from external competition, the South Korean government decided to establish a ban on imports of cars made in the EU, the USA, and Japan.

For all other imported cars, a $50 \%$ customs duty was established for the period up to 1994. Starting from 1994, the import duty on a car is $10 \%$ of its value, but an additional tax was imposed on the use of imported cars. The ban on imports of motor vehicles manufactured in the USA and the EU was valid until 1998, and those manufactured in Japan - until 1999. If the South Korean government actively supported enterprises engaged in producing and assembling automobiles and protected from competition, in relation to those specialised in the producing parts and components for automobiles, on the contrary, a policy of encouraging internal competition (although protecting against competition) was applied. The 1980s were marked by the beginning of the mass production of cars in South Korea and the export of automotive products to foreign markets (Kryvokon and Bondarenko, 2012; Ostapenko, 2015; Prikhodko, 2014; Semyrak, 2016; Akhmetshin et al., 2018).

In the 1990s, automotive products of Kia Motors, Daewoo Motors and Hyundai Motors began to gain popularity in foreign markets. The main competitive advantage of South Korean motor 
vehicles in the global automotive market was the favourable ratio of the parameters "price-quality" compared to those of vehicles produced by other manufacturers.

Strengthening of the competitive position of South Korean automakers coincided with a change in the political situation in the country, which resulted in the government's removing itself from regulating the development of the automotive industry. The difference in the political system in the country caused the emergence of new threats to the successful functioning of the South Korean automakers, in particular, a substantial increase in the cost of labour could cause losing by automobile manufacturers their main competitive advantage - the low price of automotive products. In this regard, the South Korean automakers began to organise automotive assembly plants in countries with low labour costs such as India, Malaysia, China, Poland, Romania, Ukraine, Russia, Uzbekistan. Steps have been taken to form new competitive advantages for South Korean-made vehicles: exclusive automobile designs were developed, and offices for their sale and maintenance were established in other countries (Semyrak, 2016).

The global economic crisis of 2008 had a significant negative impact on the demand for motor vehicles. To restore domestic demand for automotive products and support national automakers in the post-crisis period, the South Korean government carried out tax cuts: for example, when replacing vehicles which are more than ten years old, the special excise tax for new ones was reduced by $70 \%$, and the amount of the tax on car registration was established at a level not higher than USD2 thousand. A similar tax relief was used by the South Korean government in the 2010s to stimulate the domestic demand for plug-in cars (Ostapenko, 2015).

Automotive industry in USA. The American automotive industry has a glorious history, dating back to the end of the $19^{\text {th }}$ century - the beginning of the $20^{\text {th }}$ century. In contrast to countries where the formation of the automotive industry was provided mainly by comprehensive support of the government, the driving force of the development of the American automotive industry was, first of all, the entrepreneurial initiative of such well-known automobile designers and industrialists as Henry Ford, William Durant, Thomas B. Jeffery, John and Horace Dodge, Walter Chrysler. The Big Three of the American auto industry - General Motors, Ford, and Chrysler - began to compete with each other in the 1920s. It was the competition between these auto giants that gave rise to the continuous improvement in the design of cars, technology of their production, search for the most efficient types of fuel and possibilities to reduce the cost of vehicles (in particular, the creation of a "people's car"). The rapid development of the US auto industry in the 1900s and 1920s was accompanied by the emergence of an increasing number of automakers, including Pierce-Arrow and Peerless.

But the majority of new players in the automotive market could not stand the consequences of the Great Depression of 1929-1933. Automakers, which at that time remained in the US market, were on the verge of bankruptcy. During the Great Depression, the volume of motor vehicle production in the United States decreased four times. In 1933, this situation forced the government for the first time to interfere in the development of the automotive industry by adopting the National Industrial Recovery Act, which established new rules for doing business - a code system of fair competition for every sort of industry (Semyrak, 2016).

The codes of fair competition regulated: production volumes and sales markets; social guarantees for employees: minimum wage, maximum weekly hours, creation of trade unions, conclusion of a collective agreement; production technology (including industrial safety measures); uniform prices for products. Companies that worked under these conditions even had their own sign to mark their products. Americans traditionally bought goods with these signs, boycotting the goods that did not have them. Also, the National Industrial Recovery Act envisaged substantial volumes of the government order for industrial products (Siumar, 2008).

These measures supported the US automotive industry and created a platform for its further development. In the subsequent years, there was a gradual restoration of the development rates of the automotive industry that fell during the crisis period. The positive trends, however, practically were not retained during the Second World War. During the 1950s and 1960s, the US automotive industry 
flourished as the Big Three actively increased their production capacity, expanded the range of automotive products, and dominated the automotive market.

Unfortunately, the 1970s were full of new challenges for American automakers: the oil crises of 1973 and 1979 led to a rapid increase in fuel prices, which resulted in a growth in domestic demand for compact and fuel-efficient cars that were mainly represented in the US automotive market by a Japanese brand Toyota. Thus, under such conditions, the Big Three needed to quickly respond to the change in the structure of domestic demand by introducing their own compact and fuel-efficient vehicles. It is understood that this reaction involved a substantial transformation of the production process, which required a considerable investment. Given the catastrophic decrease in the incoming financial flow from selling motor vehicles, the implementation of such changes, especially in the short term, seemed almost impossible. As a result, in the fall of 1979, Chrysler turned to the government for help and due to federal guarantees in the amount of USD 1.5 billion the automaker managed to avoid bankruptcy (Chernikov, 2016).

Not having financial opportunities sufficient to compete with Japanese automakers effectively, US automakers were choosing the most acceptable course of interacting with their main competitors - creating joint ventures. At the same time, the main strategic goal of the interaction was precisely the introduction of the latest Japanese technologies into the production process in US automotive plants. This decision had positive consequences, and as soon as in the 1990s, the US automotive manufacturing plants introduced fuel-efficient and hybrid cars on the market.

The next challenge for the US automotive industry was a catastrophic decrease in demand for cars in the crisis year of 2008. As a result, the Big Three of the automotive industry in the United States were on the verge of bankruptcy. This situation again required active government interference, and in July 2008 the government started implementing the Federal Utilization Program for Car Expenses Reimbursement using a discount system, which envisages a discount of USD 2.5-4.5 thousand to buyers of new, more environmentally friendly, cars in exchange for the disposal of their old ones. Due to the exhaustion of the program budget (USD 3 billion), its implementation was terminated early, but 700 thousand people had managed to use it. Starting from December 2008, the US government enhanced the lending support for major automakers. In March 2009, the Administration launched the Auto Supplier Support Program (ASSP), which aimed to guarantee payment to auto suppliers, including the right to transfer the debt to third parties from the list approved by the federal government. In particular, as part of the implementation of this program, General Motors suppliers received USD 3.5 billion, Chrysler suppliers - USD 1.5 billion. In the period 20092014, the US government provided the Big Three corporations financial backing in the amount of more than USD80 billion under specific commitments (plans) for modernising and restructuring activities as part of the implementation of the Troubled Asset Relief Program (TARP). At the end of 2014, the US government completed the Automotive Industry Financing Program (AIFP), and almost $90 \%$ of the funds spent on restoring the country's automotive industry returned to the national budget (Chernikov, 2016).

\section{Analysis of the measures for government regulation of the automotive industry}

Summarising the results of studying international experience in government regulation of the automotive industry, the following main activities that were used by governments of the world to ensure the development of the automotive industry can be singled out:

1. proclamation at the national level and consolidation in the regulatory legal acts of the status of the automotive industry as a priority industry and export earner;

2. creation of favourable conditions for foreign and national investment in the automotive industry through the provision of government guarantees, tax deduction, introduction of tax holidays for investors;

3. legislative consolidation of requirements for joint automotive manufacturing enterprises (in particular, regulating and controlling the share of foreign investment in the authorised capital of automakers); 
4. licensing of international and national investment in the automobile industry (investment is allowed only if it contributes to an increase in competitiveness of domestic automakers);

5. restriction or prohibition of imports of motor vehicles;

6. restriction or prohibition of imports of components for motor vehicles in case of production of their analogues in the country;

7. establishment of ultra-high import duty on motor vehicles and their components;

8. licensing of the assembling and manufacturing of motor vehicles;

9. legislative consolidation of and control over the level of localisation of the assembling and manufacturing of motor vehicles;

10. establishment of requirements for the technical and technological base of automotive assembly plants (in particular, the mandatory availability of equipment for production of a vehicle body and engine in such enterprises);

11. provision of tax relief to manufacturers of motor vehicles and their components;

12. tax refund for exporting automakers;

13. government support for the development of related industries;

14. government programs for providing preferential auto loans and subsidies;

15. reduction of the tax rate on purchasing a car and the amount of the registration fee;

16. government loans to automakers at concessionary interest rates;

17. government guarantees to automotive enterprises' creditors;

18. government subsidies to automakers to stimulate regional development;

19. government subsidies to automakers to implement measures for modernising their enterprises;

20. government subsidies to automakers to implement measures for restructuring their enterprises;

21. government subsidies to automakers to carry out "horizontal" activities in their enterprises;

22. establishment of the minimal volume of motor vehicle production;

23. introduction of certification of automobiles;

24. government orders for motor vehicle production;

25. regulation of prices for motor vehicles and their components;

26. introduction of accelerated depreciation for commercial vehicles;

27. implementation of government utilisation programs, which envisage offering a discount on new cars in case of their exchange for old ones.

It is evident that the decision on the expediency of implementing specific measures for government regulation of the automotive industry should be made with consideration for all the relevant factors, among which the key ones (singled out by the authors based on the analysis of the previous studies (in 2019 China will cut the subsidies on the electric vehicles by a third, 2019; Shevchenko, 2016; Shevchenko, 2018; Shevchenko, 2019)) are: life cycle stage of the automotive industry (inception, growth, stabilization, top position, stagnation, decline, crisis) and the level of competitiveness (high, medium, low) of automakers.

To distribute measures for government regulation of the automotive industry by life cycle stages and levels of competitiveness of auto industry enterprises, the experts of the Ukrainian Motor Vehicle Manufacturers Association (UkrAutoprom) were proposed to evaluate, using a 5-point scale, the expediency of applying by the specific measures at individual stages of the life cycle and Ukrainian automakers' competitiveness levels in the following way:

- 5 points - highly expedient;

- 4 points - expedient;

- 3 points - rather expedient than inexpedient;

- 2 points - rather inexpedient than expedient;

- 1 point - inexpedient;

- 0 points - highly inexpedient. 
Table 1. Unified model for government regulation of the development of the automotive industry (developed by the authors).

\begin{tabular}{|c|c|c|c|c|c|c|c|c|}
\hline \multirow{3}{*}{ 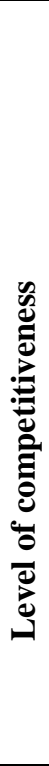 } & 焉 & $\begin{array}{c}1,2,3,7, \\
8,9,10,11, \\
13,14,15, \\
17,18,23, \\
24,26,27\end{array}$ & $\begin{array}{l}1,3,8,9 \\
12,18,26\end{array}$ & $\begin{array}{c}1,3,8,9 \\
21\end{array}$ & $\begin{array}{c}1,3,8,9 \\
21\end{array}$ & $\begin{array}{c}1,3,8,9 \\
18,21\end{array}$ & $\begin{array}{l}1,3,8,9 \\
12,19,26\end{array}$ & $\begin{array}{c}1,2,3,7, \\
8,9,11,13, \\
14,15,17, \\
19,23,24, \\
26,27\end{array}$ \\
\hline & 莺 & $\begin{array}{c}1,2,3,4,5 \\
6,7,8,9 \\
10,11,13, \\
14,15,16, \\
17,22,23, \\
24,25,26, \\
27\end{array}$ & $\begin{array}{c}1,2,3,6 \\
7,8,9,10 \\
11,13,14 \\
15,17,18 \\
23,24,26 \\
27\end{array}$ & $\begin{array}{l}1,3,8,9 \\
12,15,18, \\
26\end{array}$ & $\begin{array}{c}1,3,8,9 \\
12,21\end{array}$ & $\begin{array}{c}1,3,8,9 \\
12,15,19 \\
26\end{array}$ & $\begin{array}{c}1,2,3,6, \\
7,8,9,11 \\
13,14,15 \\
17,19,23 \\
24,26,27\end{array}$ & $\begin{array}{c}1,2,3,4,5, \\
6,7,8,9, \\
11,13,14, \\
15,16,17, \\
20,22,23, \\
24,25,26, \\
27\end{array}$ \\
\hline & e & $\begin{array}{c}1,2,3,4,5 \\
6,7,8,9 \\
10,11,13 \\
14,15,16 \\
17 \\
22,23,24 \\
25,26,27\end{array}$ & $\begin{array}{c}1,2,3,4,5 \\
6,7,8,9 \\
10,11,13 \\
14,15,16, \\
17,22,23 \\
24,25,26, \\
27\end{array}$ & $\begin{array}{c}1,2,3,4,5 \\
6,7,8,9 \\
10,11,13 \\
14,15,17 \\
23,24,25 \\
26,27\end{array}$ & $\begin{array}{c}1,3,4,5 \\
6,7,8,9 \\
11,13,14 \\
15,23,25 \\
26,27\end{array}$ & $\begin{array}{c}1,2,3,4 \\
5,6,7,8 \\
9,11,13 \\
14,15,17 \\
19,23,24 \\
25,26,27\end{array}$ & $\begin{array}{c}1,2,3,4,5, \\
6,7,8,9 \\
11,13,14 \\
15,16,17 \\
20,22,23 \\
24,25,26, \\
27\end{array}$ & $\begin{array}{c}1,2,3,4,5 \\
6,7,8,9 \\
11,13,14 \\
15,16,17 \\
20 \\
22,23,24 \\
25,26,27\end{array}$ \\
\hline & & inception & growth & stabilization & top position & stagnation & decline & crisis \\
\hline & & \multicolumn{7}{|c|}{ Stages of the life cycle } \\
\hline
\end{tabular}

* according to the enumeration of the measures for government regulation of the development of the automotive industry given in the text

Source: authors

The measure was included in the unified model for government regulation of the development of the automotive industry, provided that the average score of the expediency of its application was at least 3 points. Table 1 presents a unified model for government regulation of development of the automotive industry.

\section{Conclusion}

1. The unified model for government regulation of development of the automotive industry elaborated by the authors is a universal methodological tool for forming a set of measures for government regulation of development of the automotive industry at certain stages of its life cycle and certain levels of competitiveness of automotive manufacturing enterprises. The model is an integral part of the harmonisation model for forming the government strategy for development of the automotive industry, which provides for harmonising a set of measures for government regulation of development of the automotive industry and strategic toolkits of automotive manufacturing enterprises.

2. The prospects for further research are elaborating methodological principles for harmonising the unified model for government regulation of development of the automotive industry and the matrix model for forming strategic toolkits of automotive manufacturing enterprises within the harmonisation model for developing the government strategy for the automotive industry.

\section{References}

1. Akhmetshin, E.M., Sekerin, V.D., Pavlyuk, A.V., Shichiyakh, R.A., Allanina, L.M. The influence of the car-sharing market on the development of ground transport in metropolitan cities. Theoretical and Empirical Researches in Urban Management, 2019, Vol. 14, No. 2, p. 5-19. 
2. Akhmetshin, E.M., Vasilev, V.L., Mironov, D.S., Yumashev, A.V., Puryaev, A.S., Lvov, V.V. Innovation process and control function in management. European Research Studies Journal, 2018, Vol. 21, Np. 1, p. 663-674.

3. Andreev, O.V. Prospects of borrowing the world's practice of applying the protectionism for the development of the automotive industry. Theory and Practice of the Public Administration, 2009, No. 1, p. 287-295.

4. Chernikov, A.V. State regulation of the automotive industry: the experience of the countries of the world and the possibility of its application in Russia. Moscow: Nauka, 2016.

5. In 2019 China will cut the subsidies on the electric vehicles by a third. News of the Association of the automobile manufacturers of Ukraine "UkrAvtoprom". 2019. http://ukrautoprom.com.ua/uk/v-2019-godu-kitaj-na-tret-sokratit-dotacii-na-elektromobili [2019-05-24]

6. Kerimov, P. State policy of the automotive industry development: foreign experience and Ukrainian realities. Economist, 2017, No. 4, p. 13-18.

7. Krause, O., Maschak, A. Research of the motor vehicle industry market of China. Galician Economic Bulletin, 2018, Vol. 54, No. 1, p. 71-76.

8. Kryvokon, O.G., Bondarenko, A.I. Ukrainian and world experience in the development of the automotive industry. Bulletin of the Kharkiv National Automobile and Highway University, 2012, No. 56, p. 14-19.

9. Ostapenko, A.V. State support for the development of the bus industry sub-sector of Ukraine. Kharkiv: Konstanta, 2015.

10. Prikhodko, V.P. Stimulation of the automobile industry is the potential possibility for the reorientation of the Ukrainian economy. Effective Economy, 2014, No. 3. http://www.economy.nayka.com.ua/?op=1\&z=2854 [2019-05-24]

11. Ripetskiy, A.V., Mirolyubova, T.I., Freylekhman, S.A. Analysis of factors that determine the possibility for automation of smoothing of product electronic model, obtained through topological optimization for the purpose of its use in the technological preparation of additive manufacturing. Periodico Tche Quimica, 2018, Vol. 15, No. 1, p. 405-413.

12. Semyrak, O.S. Planning and regulation of the automotive industry development in Ukraine. Lviv: Nauka, 2016.

13. Shevchenko, I.Yu. Mechanism for the public regulation of the automobile production development and the car sales market in Ukraine. Business Inform, 2016, No. 8, p. 36-45.

14. Shevchenko, I.Yu. Methodological and applied bases of forming the strategic sets of the automotive industry enterprises. Economy. Finances. Law, 2019, No. 2/1, p. 39-44.

15. Shevchenko, I.Yu. Methodological framework for assessing the competitiveness of automotive companies in the context of building the government strategy for automotive industry development. Bulletin of Kyiv National University of Technologies and Design. Series: Economic Sciences, 2018, Vol. 125, No. 4, p. 49-61.

16. Siumar, V. Franklin Roosevelt's "New Deal" and seven conclusions for the Ukrainian authorities. https://www.pravda.com.ua/articles/2008/11/4/3603584 [2019-05-24]

17. Stroe, G., Andrei, I.-C. Automated conflict resolution in air traffic management. INCAS Bulletin, 2017, Vol. 9, No. 1, p. 91-104.

18. The EU agreed to limit $\mathrm{CO}_{2}$ emissions by the new cars from 2030. News of the Association of the automobile manufacturers of Ukraine "UkrAvtoprom". http://ukrautoprom.com.ua/uk/v-esdogovorilis-ogranichit-vybrosy-so2-novymi-avtomobilyami-s-2030-goda [2019-05-25]

19. Toyota announced the launch of the serial production and the start of sales of the Mirai hydrogen sedan. News of the Association of the automobile manufacturers of Ukraine "UkrAvtoprom". http://ukrautoprom.com.ua/uk/toyota-obyavila-o-starte-serijnogo-proizvodstva-i-nachaleprodazh-vodorodnogo-sedana-mirai [2019-05-25] 
20. World motor vehicle production by country and type. Buses. Statistics of the International organization of motor vehicle manufacturers. 2017. http://www.oica.net/wp-content/ uploads/Buses-and-Coaches-2017.pdf [2019-05-25]

21. World motor vehicle production by country and type. Cars. Statistics of the International organization of motor vehicle manufacturers. 2017.http://www.oica.net/wp-content /uploads/Passenger-Cars-2017.pdf [2019-05-25]

22. World motor vehicle production by country and type. Trucks. Statistics of the International organization of motor vehicle manufacturers. 2017. http://www.oica.net/wp-content/ uploads/Heavy-Trucks-2017.pdf [2019-05-25]

Illia A. Dmytriiev, Inna Yu. Shevchenko, Vyacheslav M. Kudryavtsev, Olena M. Lushnikova, Tetiana S. Zhytnik

\section{The World Experience and a Unified Model for Government Regulation of Development of the Automotive Industry}

\section{Anotacija}

Straipsnis apžvelgia pasaulines valstybės valdymo praktikas taikytas automobilių pramonei. Daugiausia dėmesio yra skiriama Kinijos, Japonijos, Indijos, Pietų Korèjos, Jungtinių Amerikos Valstiju bei Europos Sajungos pavyzdžiu analizei. Buvo atlikta valstybių taikytų reguliavimo mechanizmų palyginamoji analizè, kuri atskleide jų taikymo ypatumus, iššūkius ir privalumus. Šie rezultatai padèjo išplètoti unifikuoto automobilių pramonès reguliavimo modelio kūrimą. Šis modelis remiasi produkto gyvavimo ciklo analize, todèl unifikuotas modelis apjungia skirtingas valdymo bei reguliavimo institucijas. Modelyje apibrèžtos reguliavimo praktikos yra taikomos skirtingoma produkto gyvavimo ciklo etape.

Illia A. Dmytriiev - socialinių mokslų (ekonomikos) daktaras, profesorius, Vadybos ir verslo fakulteto dekanas, Nacionalinis Kharkiv automobilių ir kelių Universitetas, Kharkiv, Ukraina

email: ekonom_pred@ukr.net

Inna Yu. Shevchenko - PhD (ekonomikos), Ekonomikos ir verslumo katedros assoc. profesorè, Nacionalinis Kharkiv automobilių ir kelių Universitetas, Kharkiv, Ukraina email: shevchenko.khnadu@gmail.com

Vyacheslav M. Kudryavtsev - PhD (Economics), Ekonomikos ir verslumo katedros assoc. profesorius, Nacionalinis Kharkiv automobilių ir kelių Universitetas, Kharkiv, Ukraina

email: $\underline{\text { slavkudr@ukr.net }}$

Olena M. Lushnikova - PhD (Economics), Ekonomikos ir verslumo katedros assoc. profesorè, Nacionalinis Kharkiv automobilių ir kelių Universitetas, Kharkiv, Ukraina email: lushnikova_om@ukr.net

Tetiana S. Zhytnik - PhD (pedagogika), Socialinio darbo, socialinès pedagogikos ir ikimokyklinio ugdymo katedros vyr. lektorè, Bogdan Khmelnitsky Melitopol Pedagoginis universitetas, Melitopol, Ukraina email: zhytnik_tetiana@mdpu.org.ua 
Illia A. Dmytriiev - Doctor of Science (Economics), Professor, Dean of the Faculty of Management and Business, Kharkiv National Automobile and Highway University, Kharkiv, Ukraine email: ekonom_pred@ukr.net

Inna Yu. Shevchenko - PhD (Economics), Associate Professor of the Department of Economics and Entrepreneurship, Kharkiv National Automobile and Highway University, Kharkiv, Ukraine email: $\underline{\text { shevchenko.khnadu@gmail.com }}$

Vyacheslav M. Kudryavtsev - PhD (Economics), Associate Professor of the Department of Economics and Entrepreneurship, Kharkiv National Automobile and Highway University, Kharkiv, Ukraine

email: $\underline{\text { slavkudr@ukr.net }}$

Olena M. Lushnikova - PhD (Economics), Associate Professor of the Department of Economics and Entrepreneurship, Kharkiv National Automobile and Highway University, Kharkiv, Ukraine email: lushnikova_om@ukr.net

Tetiana S. Zhytnik - PhD (Pedagogy), Senior Lecturer of the Department of Social Work, Social Pedagogy and Preschool Education, Bogdan Khmelnitsky Melitopol State Pedagogical University, Melitopol, Ukraine

email: zhytnik_tetiana@mdpu.org.ua 